＜資料紹介>

\title{
井上 勤の遺存書簡から
}

佐 光 昭 二

(1)

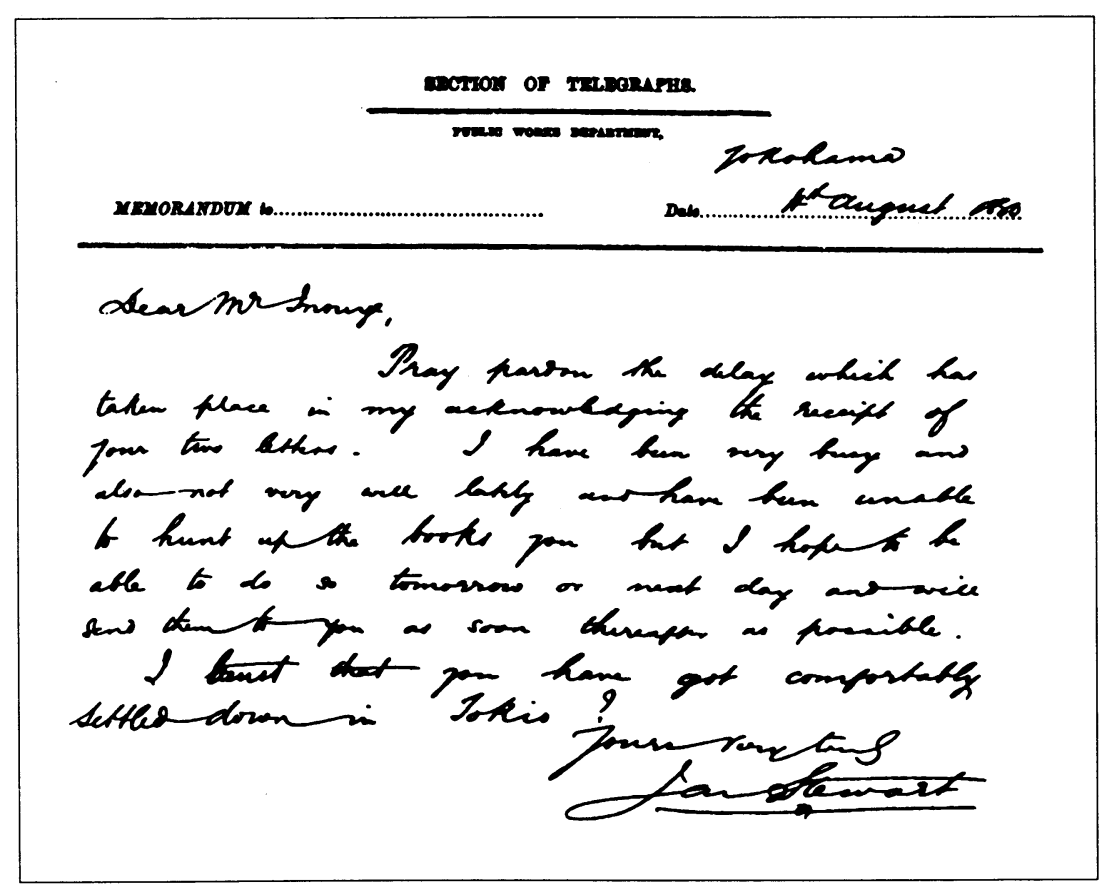

Yokohama

4th August 1880

Dear Mr Inouye,

Pray pardon the delay which has taken place in my acknowledging the receipt of
書簡は、1880年 8 月横浜在留 のジェームス・スチュワート James Stewart 加「東京鳥 森町五番地/吹田新七方/井上 勤」宛に送られたあので、勤三 男芳人氏（1918～97）より生前 


\section{英 学 史 研 究 第33号}

your two letters. I have been very busy and also not very well lately and have been unable to hunt up the books you but I hope to be able to do so tomorrow or next day and will send them to you as soon thereafter as possible.

I trust that you have got comfortably settled down in Tokio?

\section{Yours very truly \\ James Stewart}

複写にて筆者に恵与されたもの である。レターペーパーに Public Works Department (工 部省) Section of Telegraphs （電信寮）のメモ用紙を使用。 発信人のジェームス・スチュ ワートとは、いわゆる御雇外国 人である。

国籍英国

雇主工部省電信寮

職種横浜電信分局詰書記生

雇期間 明治 8 年 6 月 3 日より 3 か月、以後無期限

（参考:「官雇入表」「外国人雇人取扱参考書第二巻」外務省外交史料館所蔵）

(2)

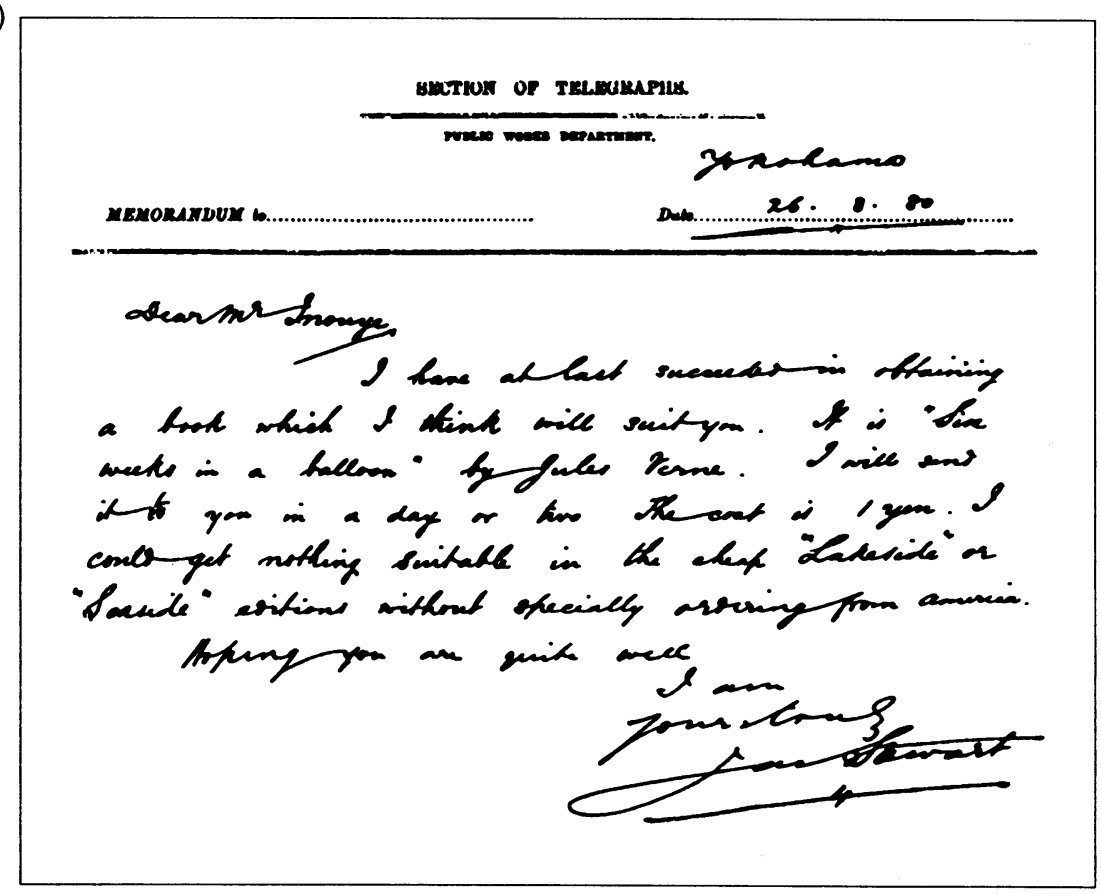




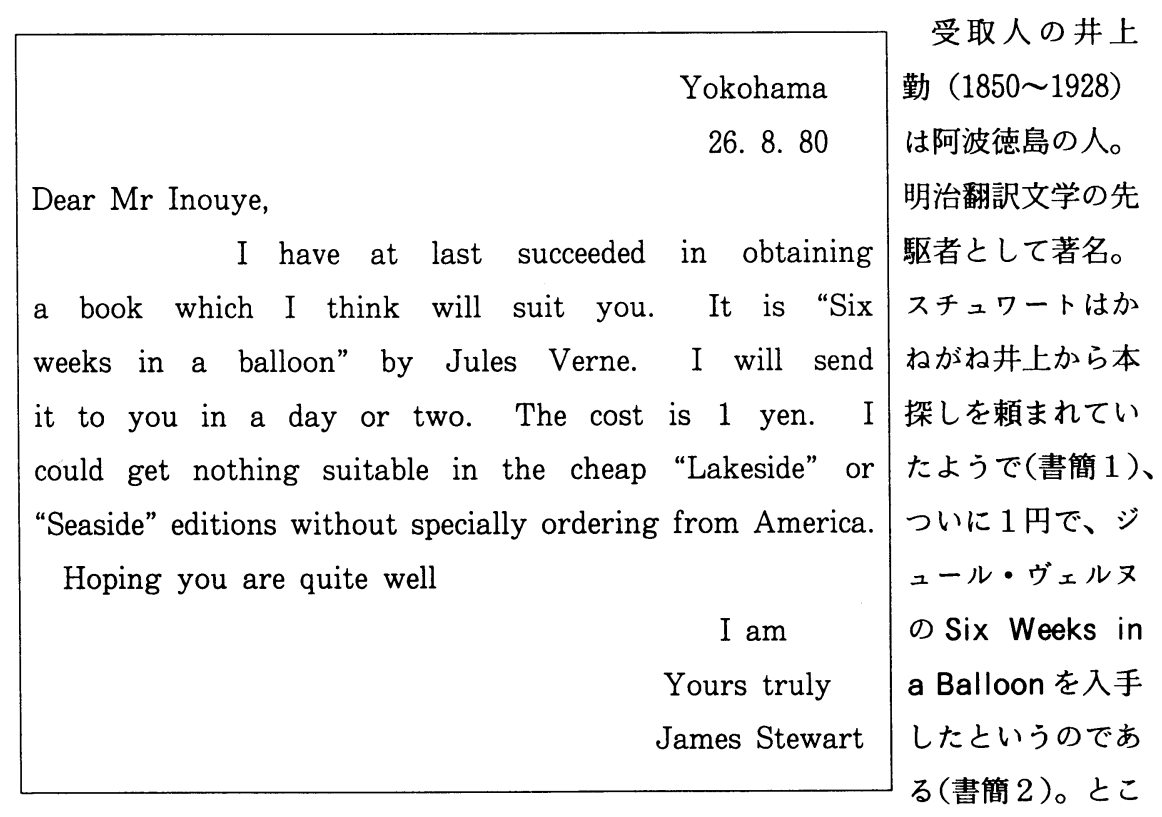

ろが、スチュワートは待ち望んでいる井上に連絡を急ぐあまりか、書名を誤ってつた えている。

同書の原書名は、Cinq Semaines en Ballon（1863）で、英訳書名は、Five Weeks in a Balloon (1870). A Guide to the Best Fiction in English (by E. A. Baker, London, 1913.) には 'Here a party of balloonists go on an exploring voyage across Central Africa.'とある。

井上 勤とスチュワートとの交流の契機は、井上が26歳のとき、明治 8 年 4 月 28 日 付で工部省電信寮十三等出仕（通訳・翻訳業務）に始まると想定される。スチュワー トの電信寮雇用はその 1 か月後のことで、両者の間には何かと頻繁に接触があったこ とであろう。

同10年 1月11日、電信寮が廃され電信局と改称。これを機に井上＼cjkstart勤は郷里徳島に 帰り教育界に入ることになるが、ジュール・ヴェルヌの『亜非利加内地三十五日間空 中旅行』を刊行した同16年（1883）のころは、大蔵省関税局を経て文部省編輯局の官 員となり、生活の基盤を持ちながら本格的に翻訳活動を開始していた。一方、ジェー ムス・スチュワートのほうは、同18年12月に工部省が廃止になり、新設の莪信省に電 信御雇外国人として雇用継続となった。 
なお井上＼cjkstart勤は、そのころ海外情報や図書の入手に、横浜入港の米艦乗組員とあコ ンタクトをとっていたようである。

(3)

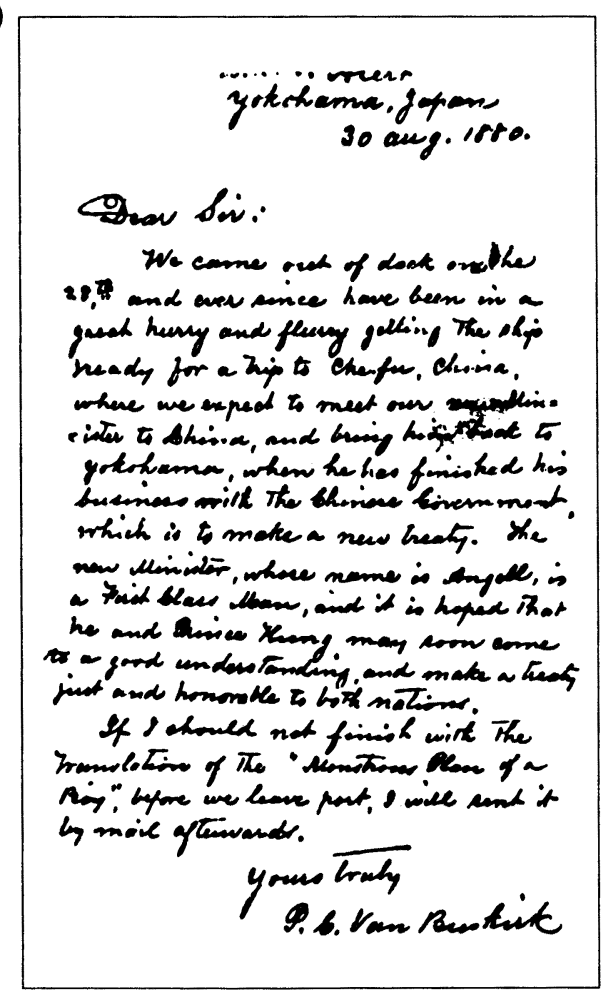

U.S. S. Alert
Yokohama, Japan
30 Aug. 1880.
Dear Sir,
We came out of dock on the
28th and ever since have been in a
great hurry and flurry getting the ship
ready for a trip to Che-fu, China,
where we expect to meet our new Min-
ister to China, and bring him back to
Yokohama, when he has finished his
business with the Chinese Government,
which is to make a new treaty. The
new Minister, whose name is Angell, is
a First Class Mean, and it is hoped that
he and Prince Kung may soon come
to a good understanding, and make a treaty
just and honorable to both nations.
If I should not finish with the
translation of the "Monstrous Plan of a
Boy", before we leave port, I will sent it
by mail afterwards.
Yours truly
P. C. Van Buskirk

(3)の葉書の宛名は、「東京二葉町七番地/井上 勤君」とあり、明治 13 年 9 月 1 日 付の横浜消印になっている。アラート号は、同年 7 月 9 日、横浜に入港。U.S. sloop of war, Commander Huntington, 1,020t., 4 guns (The Japan Weekly Mail July $10,1880)$.

同艦乗組員のブスカークと井上 勤との交誼の経緯については分からない。ともあ れこの葉書の末尾に見る “The Monstrous Plan of a Boy” とは、Benjamin Disraeli の作品 Vivian Grey（1826）のことでは。

井上はブスカークに、大冊の同原本を表題・内容ともに日本人に分かり易いように 書き直してもらい、それを翻訳したのではないだろうか。これは「政海冒険 大膽書 生」のタイトルで、雑誌『文學之花』（拓園社）に明治20年12月創刊号から数回連載 
井上 勤の遺存書簡から

されたが、思いきった奇抜な表題で読者の目を引きつけることは井上の最も得意とす るところであった。ちなみに、Vivian Greyについて研究社の『英米文学辞典』に は「功名心に燃える大胆な青年 Vivian Grey は新政党樹立を企てて失敗し、 Cleveland との決闘に勝ったが、大陸に渡り、種々の経験を積む。」と解題がある。

(4)

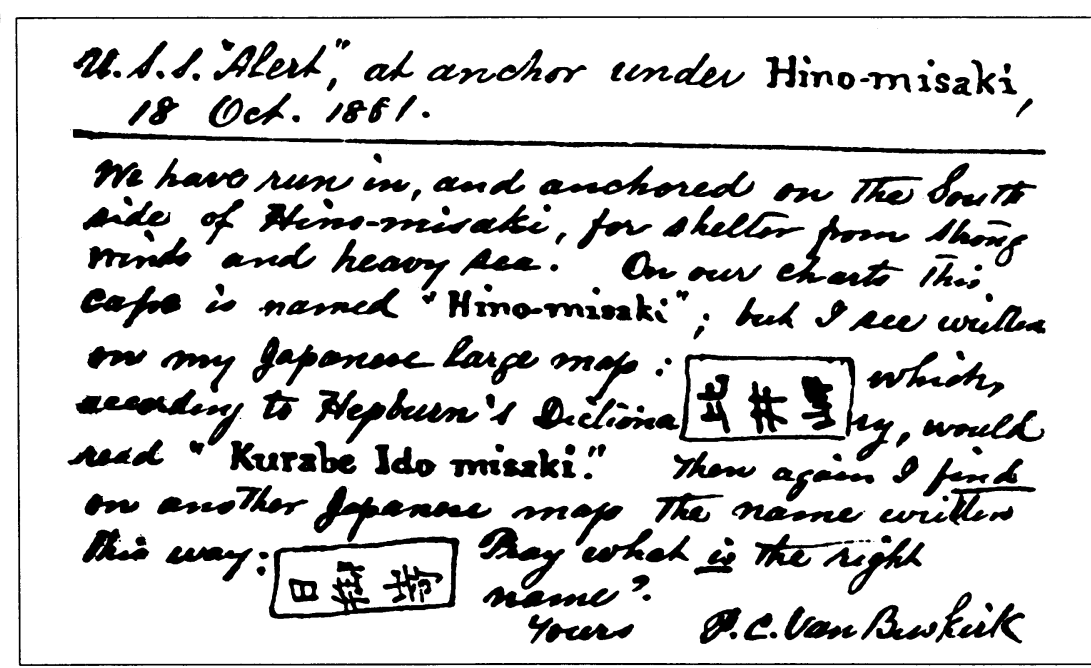

U.S.S. "Alert", at anchor under Hino-misaki, 18 Oct. 1881.

We have run in, and anchored on the South side of Hino-misaki, for shelter from strong winds and heavy sea. On our charts this cape is named "Hino-misaki", but I see written on my Japanese large map: 泣貫 which, according to Hepburn's Dictionary, would read "Kurabe Ido misaki." Then again I find on another Japanese map the name written this way: 四揤 Pray what is the right name?

Yours P.C. Van Buskirk
アラート号は、その後 1 年を 経て再び来日。同艦は 1881 年 10 月16日に初めて横浜から神戸へ 向けて航海するが (J.W.M. Oct. 22，1881)、乗組員ブス カークは、20日に、上掲の書簡 (4)を神戸から「東京南神保町 12 番地 $/ \mathrm{T}$. Inouye Esq.」宛に 送っている。同書簡は、(1) (3) 書簡における海外図書入手経路 の話とは関係ないが、へボンの 辞書を艦内に持ち込み、熱心に 日本を勉強するブスカークとは、 一体いかなる人物だろうか。博 


\section{英 学 史 研 究 第33号}

雅の士の御示教を得たい。

彼はその後む井上 勤とは頻繁に文通し、自ら「林堂」と名乗り、その印判まで作 っている。

以上、井上 勤は、彼一流の手法で来日外国人と接触して海外図書の入手をはかっ ているが、外国図書輸入システムの十分確立していなかった当時、翻訳事業には何か と大変な苦労があったものと察せられる。 